\title{
LANGUAGE VARIATIONS IN MADURESE ACROSS REGIONS AND AGE GROUPS: LOOKING AT SYNTACTIC AND LEXICAL VARIATIONS
}

\author{
Syariful Muttaqin ${ }^{1}$, Sahiruddin ${ }^{2}$, Iis Nur Rodliyah ${ }^{3}$ \\ ${ }^{1}$ Universitas Brawijaya, smuttaqin@ub.ac.id \\ ${ }^{2}$ Universitas Brawijaya, shrdn@ub.ac.id \\ ${ }^{3}$ Universitas Brawijaya, iis.nurrodliyah@ub.ac.id
}

\begin{abstract}
This research is aimed to describe the syntactic and lexical variations of the Madurese language based on different ages and regions in Madura. This is due to the changing phenomena of the language, namely Madurese, due to socioeconomic and technological development. Participants of this study were youths and old groups from different regions. Data were analyzed quantitatively and qualitatively in accordance to the research problems. It was found out that syntactically, Madurese has similar basic word order structure to that of Indonesian. The possessive structure is determined by the last sound of the word, either vowel or consonant. Other structures, noun phrase, prepositions, adjective clause, nonverbal clause, and existential clause are much similar to those of Indonesian language. No differences were found in terms of syntactic variations among different ages and regions in Madura. In terms of lexicon, some variations do occur as attributed to the socio-cultural background of each speaker. The level of politeness indicates that the social level influences the choice of lexical terms used by speakers based on different ages and regions in Madura.
\end{abstract}

Key Terms: Syntactic structures, lexical variations, age, regions, Madurese

DOI: https://doi.org/10.33479/klausa.v3i01.193

\section{INTRODUCTION}

Language undergoes changes in line with the developing society (Swan, 2011). Due to the changes, there will be some variations of a language depending on some factors, such as regional or social (Yule, 2014). Although speaking the same mother tongue, for example Sundanese, Cirebonese speak Sundanese language, rather differently from Bantenese in many aspects, such as in sounds, sentence structure, word order, etc. (Haerani \& Muslim, 2008). Madurese is a language spoken by Madura people. Madura is a small island in East Java, located in the north-eastern part of East Java. There are four main districts in Madura, Sumenep, Pamekasan, Sampang, and Bangkalan regions. Historically, Madurese language is "a member of the Malayo-Sumbawan subgroup of the Western Malayo-Polynesian branch of the Austronesian language family" (Adelaar, 2005 and Gray, Drummond and Greenhill, 2009, cited in Davies, 2010, p. 4). Though Madurese is the common language, it is assumed that 
geographically, people from these four different regions will speak different language varieties. Geographical location is probably the most-studied social factor affecting variations. A study of regional differences, Dialectology, usually seeks to see how different regions influence the language the people speak.

In addition to its geographical factor, age factor also can contribute to new variations in language development (Yule, 2014). This is the case with Indonesian or Javanese, in which it is clearly seen from the reality that older and younger Indonesian or Javanese speak both languages differently. Older Indonesian tend to speak Indonesian more formally, but younger generations will tend to speak rather differently by involving Jakartanese dialects or using code mixing or switching, which is also influenced by social status of the speaker.

Madurese people are quite mobile and dynamic. They now spread all over Indonesia or even abroad (Davies, 2010). Younger Madurese go outside Madura for studying in universities. Madurese people also go outside for economic reasons, and this phenomenon will then affect language development in terms of lexical and syntactic features.

Upon using a language to communicate to one another, people form a language community, such as, related to this research, the Madurese language community, might speak differently from each other. Within the Madurese community, who are mainly separated socially and geographically (into four main regions), the differences in how the community members use the Madurese language may occur. In the field of linguistics, as being notified by Kreidler (2009, p.19), "When people who have the same native language can understand one another but still notice consistent differences in each other's speech, we say they speak different dialects of that language".

In addition, the variation can be viewed as either diachronic or synchronic. According to Yule (2014, p.236) diachronic language variation is resulted from the historical perspective of change through time; while, synchronic variation is in terms of differences within one language in different places and among different groups at the same time. Yule (2014, p. 244) notifies that "While differences in vocabulary are often easily recognized, dialect variations in the meaning of grammatical constructions are less frequently documented." Moreover, the regional dialect variation has been broadly acknowledged and become the source of some humor for people living in other regions (Yule, 2014).

According to Swan (2011, p. 60) "language change may be a natural and universal phenomenon...". Therefore, language variations or language form alternatives may occur in a society speaking and using the same language. For example, there is a variation for standardized English statements of "I don't know anything" or "I'm no working the day" (Swan, 2011, p. 63). Swan (2011) also states that this variation is common because languages change following the course of time, the regional dialects, the individual speakers, and the different situations.

In addition, the variation can be viewed as either diachronic or synchronic. According to Yule (2014, p.236) diachronic language variation is resulted from the historical perspective of change through time; while, synchronic variation is in terms of differences within one language in different places and among different groups at the same time. Yule (2014, p. 244)

46 | Language Variations in Madurese across Regions and Age Groups 
notifies that "While differences in vocabulary are often easily recognized, dialect variations in the meaning of grammatical constructions are less frequently documented." Moreover, the regional dialect variation has been broadly acknowledged and become the source of some humor for people living in other regions (Yule, 2014).

There have been some studies to describe Madurese Syntax (Davies, 2010), Madurese phonology, lexicon, syntax, (Sofyan, 2007), and verb forms (Azhar, 2010.). These have been a major reference in looking at how standard Madurese is. However, there has been no study investigating the different uses of the language based on different regions and by different age groups. This research is aimed to identify the variations of Madurese by looking at syntactical and lexical features of Madurese based on regional and age group differences.

\section{METHODOLOGY}

This research is a descriptive study to investigate variations of lexical and syntactic performance of Madurese language performed by the Madurese people. This research applied both quantitative and qualitative method. Quantitative method was used to look at the number of linguistic performance by the participants, younger and older generations of Madurese. Also it tried to look at differences in the performance of both lexical and syntactic performance by both age groups. Qualitative method was used to describe patterns of the participants' linguistic performance so that a deep description and analysis of the patterns were also identified.

As mentioned in the literature review, the syntax of Madurese particularly from Bangkalan regency was studied and published by Davies (2010). This study then tried to involve two other regions, Pamekasan and Sumenep. Thus, the regions covered in this study are three different regions. In particular, participants across three regencies are 90 Madurese students whose ages range from 15 to 17 and 30 teachers (10 teachers and 30 students from each regency). These two different groups in ages were expected to represent two different generations as set out in the second objective of this study.

Madurese syntax was assessed using the instrument developed by the researchers. It is a written test consisting of Indonesian sentences representing Madurese syntax as adopted from Davies's (2010) book "A grammar of Madurese". It covers sentences of basic word order, nonverbal clauses, existential clauses, verbal clauses (transitive, intransitive, ditransitive), exclamatory clauses, hortative clauses, imperative clauses, and comparative and superlative clauses). About 50 items were used as instrument to collect data about Madurese syntax or grammar (see Appendix 1).

The data collection was conducted after the permission from school principals at each regency was approved. After permission was obtained, the researchers contacted some teachers and students to participate in this research. The data were collected outside of class time. Regarding procedures for data collection, the participants were assessed individually beginning with a trial sample provided by the researchers. The participants completed the paper-based written expression instrument within 30 minutes. 


\section{FINDING AND DISCUSSION}

\section{Syntactic Variations Among Regions}

This study focuses on the clause level of Madurese language, starting from simple sentence and complex sentence.

\section{Simple Sentence Basic Word Order.}

All utterances indicate that the basic word order of Madurese language is Subject Verb Object (SVO) structure. This is similar to Indonesian or English language in which the basic sentence structure is subject preceding predicate. This is shown from the participants' sentences:

- Kauleh ngenom kopi. (I drink coffee)

- Abdhina ngenom ghubhi. (I drink coffee)

- Sengko' ngenom kopi. (I drink coffee)

From the questionnaire, all participants from the three regions and from the same generations produced the same order, that is SVO order.

\section{Prepositions}

Prepositions occur in Madurese language. However, in this study only two prepositions are investigated. The finding is as follows.

\begin{tabular}{llll}
\hline To & Bangkalan & Pamekasan & Sumenep \\
\hline$K a$ & $60 \%$ & $60 \%$ & $100 \%$ \\
Dha & $40 \%$ & $40 \%$ & \\
\hline In & & & \\
\hline$E$ & $90 \%$ & $80 \%$ & $100 \%$ \\
Neng & $10 \%$ & $20 \%$ & \\
\hline
\end{tabular}

Table 1. Distribution of Prepositions 'to' and 'in' based on regions (preference)

From the data above, this study looked at two prepositions, namely 'to' and 'in'. It is shown that the prepositions used are ' $k a$ ' and ' $d h a$ ' for 'to', and ' $e$ ' and 'neng' for 'in'. From the finding, it is also shown that the majority of the respondents use ' $k a$ ' for 'to' and ' $e$ ' for 'in'.

The finding also indicates that the structure of preposition is put before the noun, as in:

- Abdhina mangkat da Sorbhajah.(I go to Surabaya)

- Kaule meyos dha' Sorbaja. (I go to Surabaya)

- Kauleh meyos ka Sorbejeh. (I go to Surabaya)

- Rino bedeh e kantor (Rino is at the office)

- Rino bedhe neng kantor. (Rino is at the office) 


\section{Noun Phrase}

Noun phrase in this study is shown by two ways:

1. Noun + Adjective (NAdj) structure, such as in 'Ka'dissah si mored penter' or 'Aruah mored penter' (He is a smart student)

a. Noun $+\mathrm{se}+$ Adjective structure, such as 'Jiah mored se penter'. (He is a smart student)

However, mostly, Noun+Adjective is mostly used by the participants which is $90 \%$ of utterances use this adjective clause structure.

\section{Non-verbal Clause}

This structure shows that the predicate of a Madurese sentence has no verb in it. Rather, it uses Noun, adjective, or Adverb phrase as the predicate. The structure of the sentence consists of Subject + Non-verbal Clause marker (ka/ruah, paneka, ka'isah) for 'that'

The Non-verbal clause markers are

- Pamekasan: ka/ruah, paneka, such as in "siti paneka ghuru" (Siti is a teacher).

- Bangkalan: $k a /$ ruah, such as in "Bebini' jeria anyanyi se bagus' (The woman is a good singer), gha/panekah, ka'isah, jareya, ka'dissah, such as in "Siti ka'dissa guru" (Siti is a teacher).

- Sumenep: jeria/jareya, such as in "Bebini' jeria anyanyi se bagus' (The woman is a good singer).

From the data, it was found that ka/ruah is the mostly used NV Clause marker, compared to other markers.

\section{Suggestions}

- The findings presented in this section are not clear for non-Madurese readers.

- To make them clear, put the non-verbal clause marker (ka/ruah, paneka, ka'isah for 'that') in a complete sentence. See also the suggestion for "glossing" given on the evaluation form.

\section{Possessive}

The data indicate that in Madurese language, possessive depends on the last sound of the word, either vowel or consonant sound. If the last sound is vowel, then the affix ' $n a$ ' is added, such as in 'guru-na', and if the last sound is consonant, then possessive is shown by doubling the last sound, as 'motorrah, mobilleh' (his car).

\section{Existential Clause}

Existential clause is shown by 'There+ N/NP (Adverb Phrase) structure. In Madurese language 'bada/bede' is used equivalent to 'there' in English. From the finding, it is shown 
that all utterances have 'bada/bede' at the beginning of the sentence. Some utterances containing existential clause are as follow:

- Bede lalake' se andi' anak sittong anyama Pote (There is a guy who has one son named Pote)

- Bedeh embik e teneyan budih (there is a goat at the backyard)

- Bedeh kadeddiyen ane. (There is a strange accident)

\section{Relative Clause}

From the finding it is shown that in relative clause, the relative pronoun used is 'se' which is similar to 'that/which/who/whom' in English. All utterences produced by the participants use this pronoun 'se' to modify the noun using relative clause, such as in the following sentences:

- Mored se deteng telat bekal eokom (The student who came late will be punished)

- Mored se dapa abhrit bhit bhadih e hokom. (The student who came late will be punished)

- Mored se deteng telat bekal e okom. (The student who came late will be punished)

\section{LEXICAL VARIATION ACROSS AND BETWEEN AGES IN MADURESE: SUMENEP}

In addition to syntactic patterns and variations in Madurese language, this study is also concerned about the lexical variation across and between ages within two regencies from different ends of Madura. From the data, it was found that lexical differences occurred in some sentences produced by Madurese people in this study. Dealing with this, this study first presented general information of how one Indonesian lexicon was illustrated in many terms in Madura. Then, the lexical variation between Sumenep and Bangkalan across participants was presented, followed by more detail differences of lexical expression between ages for each regencies. The table 1 showed that thirteen words containing lexical expression variations in this study. Generally, one lexicon showed various Madurese lexical variations in which some was expressed quite differently in each regency in Madura.

Generally, this study revealed that one lexicon in Indonesian language was illustrated in many ways in Madurese language involving first person singular pronoun (I: kaule, sengkok, buleh, abdhina), third person singular (He/She: girowa, genika, paneka, jeriyah, jerowa, rowa/jerowa, ajuah, ka'dissak, jiah, sampeyan, bekna), demonstrative (that: genika/paneka/neka, juah, jiya, jeriyah, ka'dissak, rowa, enggerowa), prepositions (to: $k a$ and dha'; behind: budhi, bingkeng), quantifiers (few: sakonek, diddhi'), noun (house: roma, compok, bengko; student: siswa, mored, kanak; dog: bhurus, pathe'), verb (drink: ngenom, neddha, adhe'er; go: meyos, mangkat, ajelen entar), and adjective (smart: phenther, pelak, tarbuka; good/nice: bhegus, becce', sae, salpak, lebur, mapan). Table 1 shows the patterns of lexical variation found in this study. 


\begin{tabular}{|c|c|c|c|c|c|}
\hline No. & Items & $\begin{array}{c}\text { Teachers } \\
(\mathrm{n}=9)\end{array}$ & $\begin{array}{c}\text { Students } \\
(\mathrm{n}=30)\end{array}$ & $\begin{array}{c}\text { Teachers } \\
(\mathrm{n}=10)\end{array}$ & $\begin{array}{l}\text { Students } \\
(\mathrm{n}=28)\end{array}$ \\
\hline \multirow[t]{5}{*}{1} & I (first person singular) & & & & \\
\hline & Kaule & 4 & 17 & 5 & 0 \\
\hline & Sengkok/Engkok & 1 & 7 & 2 & 25 \\
\hline & Buleh & 1 & 2 & 0 & 0 \\
\hline & Abdhina & 3 & 4 & 3 & 5 \\
\hline \multirow[t]{12}{*}{2} & $\mathrm{He}$ (third person singula) & & & & \\
\hline & Gi(e)rowa & 0 & 0 & 7 & 0 \\
\hline & Genika & 0 & 0 & 1 & 0 \\
\hline & Paneka & 4 & 6 & 0 & 0 \\
\hline & riyah (Su: Jeriyah) & 1 & 3 & 0 & 17 \\
\hline & rowa/arowa (Su: Jerowa) & 3 & 8 & 0 & 12 \\
\hline & Dia & 0 & 0 & 0 & 1 \\
\hline & Ajuah & 1 & 4 & 0 & 0 \\
\hline & ka'dissak & 0 & 1 & 2 & 0 \\
\hline & Jiah & 0 & 5 & 0 & 0 \\
\hline & Sampeyan & 0 & 1 & 0 & 0 \\
\hline & Bekna & 0 & 2 & 0 & 0 \\
\hline \multirow[t]{9}{*}{3} & That (Demonstrative) & & & & \\
\hline & Genika/Paneka/Neka & 5 & 16 & 2 & 0 \\
\hline & Juah/Juwa & 1 & 2 & 0 & 0 \\
\hline & Jiya & 1 & 4 & 0 & 0 \\
\hline & ka'dissak & 1 & 1 & 0 & 0 \\
\hline & rowa/arowa (Su: Jerowa) & 1 & 5 & 2 & 24 \\
\hline & Jereya & 0 & 1 & 2 & 5 \\
\hline & Itu & 0 & 1 & 0 & 1 \\
\hline & Enggerowa & 0 & 0 & 4 & 0 \\
\hline \multirow[t]{3}{*}{4} & To (Preposition) & & & & \\
\hline & $\mathrm{Ka}$ & 8 & 25 & 8 & 30 \\
\hline & dha' & 1 & 5 & 2 & 0 \\
\hline \multirow[t]{3}{*}{5} & Behind (Preposition) & & & & \\
\hline & Budhi & 6 & 21 & 7 & 30 \\
\hline & Bingkeng & 3 & 9 & 2 & 0 \\
\hline \multirow[t]{4}{*}{6} & Few (Quantifier) & & & & \\
\hline & Sakonek & 5 & 13 & 10 & 30 \\
\hline & diddhi' & 4 & 15 & 0 & 0 \\
\hline & Sedikit & 0 & 2 & 0 & 0 \\
\hline \multirow[t]{4}{*}{7} & Student (Noun) & & & & \\
\hline & Siswa & 0 & 9 & 3 & 10 \\
\hline & Mored & 9 & 16 & 7 & 20 \\
\hline & Kanak & 0 & 5 & 0 & 0 \\
\hline \multirow[t]{4}{*}{8} & House (Noun) & & & & \\
\hline & Roma & 6 & 18 & 9 & 23 \\
\hline & Compok & 3 & 12 & 0 & 0 \\
\hline & Bengko & 0 & 0 & 0 & 7 \\
\hline
\end{tabular}




\begin{tabular}{|c|c|c|c|c|c|}
\hline \multirow[t]{4}{*}{9} & Dog (Noun) & & & & \\
\hline & burus/bhurus & 4 & 3 & 0 & 0 \\
\hline & pathe' & 5 & 22 & 10 & 30 \\
\hline & Anjhing & 0 & 5 & 0 & 0 \\
\hline \multirow[t]{4}{*}{10} & Drink (Verb) & & & & \\
\hline & Ngenom & 9 & 30 & 6 & 30 \\
\hline & Neddha & 0 & 0 & 4 & 0 \\
\hline & adhe'er & 0 & 0 & 0 & 0 \\
\hline \multirow[t]{5}{*}{11} & Go (Verb) & & & & \\
\hline & Meyos & 5 & 18 & 2 & 0 \\
\hline & Mangkat & 4 & 12 & 8 & 28 \\
\hline & Ajelen & 0 & 0 & 0 & 2 \\
\hline & Entar & 0 & 0 & 0 & 0 \\
\hline \multirow[t]{4}{*}{12} & Smart (Adjective) & & & & \\
\hline & Phenter & 9 & 28 & 9 & 30 \\
\hline & Pelak & 0 & 2 & 0 & 0 \\
\hline & Tarbuka & 0 & 0 & 1 & 0 \\
\hline \multirow[t]{7}{*}{13} & Good/Nice (Adjective) & & & & \\
\hline & beghus/begus & 6 & 23 & 8 & 29 \\
\hline & becce' & 1 & 2 & 2 & 0 \\
\hline & Sae & 2 & 3 & 0 & 0 \\
\hline & Salpak & 0 & 2 & 0 & 0 \\
\hline & Lebur & 0 & 0 & 0 & 1 \\
\hline & Mapan & 0 & 0 & 0 & 0 \\
\hline
\end{tabular}

Table 2. Lexical variations in Madurese language across and between ages

Looking at the most frequently used lexicons in both regencies, some lexical expressions were found the same in the expression of prepositions (to/ka; behind/budhi), student (mored), house (roma), dog (pathe'), drink (ngenom), smart (penther), and good (bhegus). Lexical differences found contain some expressions to illustrate first person singular (I), third singular person (He/She), demonstrative (that), quantifier (few), and verb (go). The address term "I" (first person singular) used in Sumenep was dominatly expressed by "Kaule" while the word "Sengkok/Engkok" was largely used in Bangkalan across participant. Meanwhile, for third singular person (He/She), Sumenep people preferred to use "Jeriyah" while Bangkalan people used the word "Rowa/Arowa".

For demonstrative (that), the word "aroa/jerowa" was mainly used in Sumenep and "Paneka/Geneka/Neka" was mostly expressed in Bangkalan. This study revealed lexical differences in expressing quantifier word "Few" showing that Sumenep people often used frequently the word "Sakonek" while Bangkalan people used the word "Dhidhik". The verb 'go' was also expressed quite differently in both regencies in a way that the term "mangkat" was used in Sumenep and "meyos" used in Bangkalan. In addition to the most dominantly lexical expressions above, presenting lexical variations in more details from a number of expressions used between two regencies was also of interest in this study. For instance, for 
preposition "behind", the word "budhi" and "bingkeng" was used in Bangkalan while in Sumenep the word "budhi" was the only one used. For more detail see Table 1.

Looking from lexical variations between ages, this study reviewed some lexical variations from the results from each regency. In Sumenep, older participants prefered to use "kaule", while younger participants use "sengkok" to express first person singular. In Bangkalan, both older and younger participants showed the same expression "kaule" for first person singular. Lexical expression for third person singular in Sumenep was "rowa/girowa" by older people and "jerowa" by younger people. Whereas in Bangkalan, older participants preferred more using "panika" to "rowa" as dominantly used by younger generation. For demonstrative "That", older people in Sumenep used "enggerowa" while younger people used "jerowa/rowa". In Bangkalan both group of participants had the same expression "panika" to illustrate demonstrative 'that'. However, lexical variations were not evident for the rest of lexical expressions, such as to (ka), behind (budhi), student (mured), house (roma), dog (pathek), drink (ngenom), go (meyos/mangkat), smart (penther), and good (beghus).

In sum, lexical variation between ages were only evident in the lexical terms to illustrate the address terms of first person singular, third person singular, and demonstrative (that). It may be that such differences were driven by the underlying principles of politeness levels carried by each participant in each regency. For example, the term "kaule" is more polite than "sengkok" in illustrating first person singular.

\section{DISCUSSION}

This study has found that Madurese language has its own syntactic structure. However, this study only focuses on certain syntactic structures: basic word order, adjective phrase and clause (relative clause), possessive marker, Existential clause.

Madurese language has its order which is similar to that of Indonesian and English structure, that is SVO structure. This is shown by Davies' study as well that Madurese structure is Subject Predicate structure. This is due to the fact that Madurese language is influenced by grammar of that Indonesian or Malay language as it is in the same region. This structure is then much easier for Madurese to acquire the native language or Non-Madurese people to learn or follow the language in interaction.

Madurese language has its Subject preceding predicate or verb. This is in line with previous studies (Mayasari, 2014) that states that Subject mostly precedes predicate in most languages in Indonesia. The verb form in Madurese is also mostly initiated by the morpheme $n g$ - such as ngenom (drink), ngakan (eat). Object of the verb has no specific rule. It is as long as it is noun, then it can be object. The object should also be the subject for passive construction. However, since this study does not look at passive form, no further discussion on passive is given her. So, it can be generated that Similar to Indonesian syntax, the basic structure of Madurese is Subject Predicate structure, though in some cases may be possible to have missing object or subject.

Prepositions are found to be differently used among regions. The prepositions studied here are to and in. The use of $k a$ and $d a$ are found to be used for $t o$, with Sumenep respondents all using $k a$ while Pamekasan and Bangkalan using $k a(60 \%)$ more than $d a(40 \%)$. The same 
also occur in the use of preposition $e$ and eng for in English). All respondents from Sumenep prefer using $e$ instead of eng. However, respondents from Bangkalan and Pamekasan using both, but with the use of $e$ more than eng. The difference of use might be due the politeness level of each regional dialect, with Sumenep is known to be more polite. Therefore, Sumenep dialect prefers higher term for the preposition.

Adjective phrase is found to have two structures, without and with a connector sewhich is yang in Indonesian. This form seems to be optional, depending on the speaker's choice, such as Ajueh mored penter or Jiah mored se penter. Both have no difference in meaning. They are just variations among speakers in producing adjective phrases. Therefore, it can be seen from the finding that to form adjective phrase, the structure is N(se)Adj, with the noun preceding the adjective. However, further investigation should be done whether there is a certain difference, either in meaning or in structure with the presence of non-presence of sein Madurese adjective phrase.

Non-verbal clause is found in some utterances produced by the respondents. This is similar to the function of determiner to show definite noun. There are variations in the marker: ka/ruah, paneka, ka'isah, jeria/jareya. These markers are used to make the noun either subject or object has definite meaning. Compared to English, Madurese language has more variations in showing the definite noun. This study found also that the markers vary in the sound, such as karuah or ruah. This might be to indicate politeness, with $k a$ - used to add the degree of politeness.

Possessive in Madurese is indicated by two ways. It depends on the last sound of the noun, either vowel or consonant sounds. This might be due to the ease of pronunciation for the possessive such as in the word guruna that is by adding -na after the word. In contrast, if a word ends in consonant sounds, such as motor or mobil, the possessive is shown by doubling the las consonant sound of the word, becoming motorrah or mobillah. This is called Gemination. So, from this finding, the last sound in a word plays important determiner for showing possessive in Madurese language.

Existential clause is also present in Madurese. It is clauses that simply assert the existence of an entity (concrete or abstract) are frequently used to introduce an entity into the discourse (Davies, 2010). This is to indicate non-definite subject for a sentence or sometimes called as dummy subject. The existential clause is marked by the use of word bada, which is equivalent to ada in Indonesian or there in English. However, if in English there is auxiliary after there, but in Madurese, there is no Auxiliary. Instead, after bada Noun directly follows, which then can be modified by a phrase, mostly adverb phrase. This can be seen from the examples Bada embik e taneyan bingkeng or Badha kejadien aneh.

Relative Clause in Madurese is much similar to that of Indonesia language, with the use of the word 'yang' to connect the noun and the modifying clause or dependent clause. In Madurese, the word se is the most commonly used word to form adjective clause. It can be seen from the utterances, such as Peraoh se rosak ka'issah e pabeccek sareng morettah Pak Moko and Mored se deteng telat e hokom. The structure is found the same among regions in Madura, which shows that they have the same structure to form relative clause. It is clear that in 
Madurese the relative clause is consistent with the majority of universal tendencies posited in the word order literature (Davies, 2010.

In addition to syntactic variation, Lexical variation is also found in this study. The variation can be based on geographical and also social. The geographical factor does influence the variation as each region is closest to different region. Politeness is also considered the factor for the lexical variation, such as the use of engko, sengko, kawula, abdina which vary from low to high degree of politeness.

\section{CONCLUSION AND SUGGESTION}

Madurese language has different structural and lexical variations. This study has found how regional factor influences the language syntactically and lexically. In terms of syntactic variation, the basic word order remains the same among regions in Madura. No difference is found among all three regions. Adjective phrase can be formed by either adding the word se or not. Prepositions either by using $k a$ or $d a$ for to is found to be different among regions, with Sumenep all using $k a$ compared to Bangkalan and Pamekasan using $k a$ mostly and $d a$ for the rest. Other syntactical feature tends to be relatively same among regions. In addition, lexical variations exist in Madurese language. There are variations among regions in Madura. The existence is attributed to the regional difference and degree of politeness triggering the use of certain terms or lexicons among people in Madura.

This study is a preliminary study for describing syntactical and lexical variations among regions in Madura. There are many aspects covered in either syntactic or lexical aspect. The researchers do hope that this research provides a solid ground for future studies, which can be directed toward specific aspect of grammar, phonology, or morphology. This is due to some findings or data which vary in their writing. In addition, data collection can be used by recording the utterances, rather than in written form to get the authentic language as spoken language is usually mush more real and better than the written language.

\section{REFERENCES}

Arka, I. W. and Ross, M. (2005). The Many Faces of Austronesian Voice Systems: Some New Empirical Studies. Canberra: Pacific Linguistics.

Azhar, I. N. (2010). Frasa Verbal Bahasa Madura. Jurnal PROSODI Volume 6 No. 2, July 2010 pages $85-98$.

Brown, S. \& Attardo. (2009). Understanding Language Structure, Interaction, and Variation: an Introduction to Applied Linguistics and Sociolinguistics for Nonspecialists (2 $^{\text {nd }}$ Edition). Michigan: The Michigan University Press.

Crystal, D. (2008). A Dictionary of Linguistics and Phoenetics (6 ${ }^{\text {th }}$ Edidition). Oxford: Blackwell Publishing.

Davies, W. D. and Dresser, C.A. (2005). The Structure of Javanese and Madurese Determiner Phrases. UCLA Working Papers in Linguistics, no. 12, September 2005 Proceedings of AFLA XII, Heinz \& Ntelitheos (eds.) pp. 57-72.

Davies, W.D. (2010). A Grammar of Madurese. Berlin: Walter de Gruyter

Haerani, E \& Muslim, D. (2008). The Influence of Geomorphology to Language Variation in the Western Part of Java, Indonesia. Bulletin of Scientific Contribution, Volume 6, Nomor 2, Desember 2008 
Mayasari, D. (2014). Analisis kontrastif linguistik pada bahasa madura dan bahasa Indonesia sebagai pendukung proses pembelajaran bahasa di SD Manduro Posted on 11 Januari 2014 https://dianamayasaristkipjb.wordpress.com/2014/01/11/analisis-kontrastiflinguistik-pada-bahasa-madura-dan-bahasa-indonesia-sebagai-pendukung-prosespembela

Patrianto, H. (2009). Jenis-jenis Proses pada Struktur Transitivitas Bahasa Madura. Surabaya: Balai Bahasa Surabaya, Departemen Pendidikan Nasional.

Sofyan, A. (2007). Beberapa Keunikan Linguistik Bahasa Madura. Humaniora, Volume 19 No. 3, Oktober 2007, pp.232-240

Swan, M. (2011). Oxford Introduction to Language Study: Grammar. Oxford: Oxford University Press.

Yule, G. (2014). The Study of Language. $5^{\text {th }}$ Edition. Cambridge: Cambridge University Press. 
ISSN: $2301-4822(p)$

DOI: 10.33479/klausa.v0301

\section{A 4 a Bahasa, dan Sastra}

\section{Editorial Team}

Editor-in-Chief

Journal Manager

Editors

Reviewers

Publisher

Address

Frequency
: Dr. Daniel Ginting

: Wawan Eko Yulianto, Ph.D.

: $\quad$ Prof. Dr. Patrisius I. Djiwandono

Lilis Lestari Wilujeng, M.Hum.

: $\quad$ F.X Dono Sunardi, M.A.

Dhatu Sitaresmi, MTCSOL.

Anggrah Diah Arlinda, MTCSOL.

Prof. E Sadtono, Ph.D.

Yohanna Nirmalasari, S.Pd., M.Pd.

Prof. A. Effendi Kadarisman, Ph.D.

Sisilia Halim, Ph.D.

Dr. Mundi Rahayu

Dr. Ross Wood

Dr. Leticia Araceli Salas Serrano

: Faculty of Language and Arts

Universitsas Ma Chung

: The Faculty of Language and Arts

Ma Chung University

Villa Puncak Tidar N-01 (65151)

Malang, East Java, Indonesia

Email: jurnal.klausa@machung.ac.id

: $\quad$ Twice a year 